\title{
Malawi: Making Effective Use of Aid Resources
}

\author{
Adrian Hewitt and Jonathan Kydd
}

\section{Introduction}

Malawi's resources at Independence in 1964 were so modest that the country depended on foreign support. The first Development Plan (1965-69) affirmed: 'It is essential for the fulfilment of the plans which are made and the attainment of the prospects that lie ahead for external capital to be made available to assist in the financing of economic development'. Apart from project capital, the recurrent expenditure of government had to be supported by British subsidies; and a backlog in local training and education delayed the Malawianisation of key posts in both public and private sectors. But after British subsidies to recurrent budget were eliminated in 1971, concessional flows were concentrated on new and often ambitious development projects and on technical assistance.

This second phase saw donor assistance transformed from an instrument designed to prop up a doubtfully viable economy into a stimulus for growth and expansion in a maturing if agriculture-based economy, which during most of the 1970s registered impressive growth without balance-of-payments instability. The effects of the first 'oil shock' of 1973 were weathered thanks to resilient export performance, an upturn in commodity prices, and domestically-engineered adjustment measures. Aid could be channelled largely into new projects, with relatively less regard for recurrent cost implications. Public savings were released for alternative uses; over 1978 to 1980 the government went to the Euromarkets for a spate of borrowing at floating interest rates (soon to prove very onerous).

After 1979 , the economy faltered and stagnated as Malawi began to face severe balance-of-payments problems. The role of the aid donors had to change once again. Following the initial IMF stand-by agreement of 1979, the World Bank's programme of Structural Adjustment Lending began in 1981, and this led other donors into programmes concentrating aid on measures to achieve economic policy reforms.
From Independence to 1979 , real growth in Malawi averaged 5.5 per cent per year; over 1979-84 it fell to an average of 2.6 per cent. However, the worst year of recession was 1981 , and the recovery since then has been impressive, with a 6.7 per cent growth estimated for 1984 (in the 1985 budget statement). Thus, adjustment measures are already bearing fruit, and a return to external balance is not being purchased at the expense of undue loss of output.

Donor perceptions that aid in Malawi can be applied effectively in a market-oriented environment are largely drawn from the boom years of the 1970s. Do such perceptions remain valid? A stylised account of Malawi's favourable relationship with aid donors is given below (Section 2), but reveals conflicts over policy, often resolved in Malawi's favour. Section 3 gives the breakdown of recent aid flows to Malawi, stressing the concentration on a narrow range of main donors. Section 4 reviews the sectoral input in project interventions - stressing agriculture and transport and more recent multilateral adjustment assistance. Since our findings conflict with recent assertions that Malawi suffers from the disease of 'donor proliferation', we address this question in Section 5. In Section 6 , we conclude by noting some salient features of Malawi's aid experience.

\section{Malawi as a 'Virtuous Case'}

Donors now like to see in Malawi a country whose government has consistently placed reliance on the market in resource allocation, has shown restraint in expanding public sector activities and has taken a positive view of the role of international trade. That Malawi's high aggregate growth and export performance in the 1970s was based on agriculture is another factor which lends credence to the donor view that other sub-Saharan African countries have a lot to learn from Malawi's economic policies.

In a well-known paper by Agarwala Ramgopal (1983),

WDS Bulletin. 1986. vol 17 no 2. Institute of Development Studies, Sussex 
the elements of which were reproduced in the World Bank's 1983 World Development Report, a positive correlation was established between the high GDP growth rates of the $1970 \mathrm{~s}$ and the absence of price distortions in LDC economies. Malawi was placed in a league of its own among developing countries in its efforts to avoid price distortions. Malawi scored well in six of the seven categories of pricing policy surveyed: it had adopted a flexible exchange rate policy, afforded minimal protection to local manufacturing and had not over-taxed agricultural producers in the aggregate; wages had been set at or below their opportunity costs, power tariffs were set at close to market levels, and inflation had been kept under control; only capital appeared to be underpriced.

Despite this almost immaculate bill of health from a World Bank author, the real position has some blemishes. Peasant producers of export crops had been heavily taxed in the 1970s. Then, from 1979 severe budgetary and balance-of-payments problems emerged. The causes were partly external. The high cost of the new Eurocurrency borrowing caused a rapid rise in debt service payments, and higher energy costs plus a maize harvest failure in $1979 / 80$ put further strain on foreign exchange requirements. The export base had remained very narrow (concentration on a single product, tobacco, had increased to over 50 per cent of export earnings) and worsening transit difficulties across Mozambique increased the cif cost of exports and in some cases prevented the shipping of large volumes of commodity exports.

Agricultural pricing and credit policy in the 1970s stimulated the estates, many of which were now locally owned, but had inclined towards the impoverishment of the peasantry with the result that peasant export crop production declined and the financial surpluses previously realised by taxing peasants declined with falling volumes. The actions of aid donors in support of rural smallholders had little impact in the face of the squeeze on the profitability of peasant export agriculture, and had built up severe recurrent cost obligations which had now accrued to central government.

After 1979, the IMF and the main donor governments became primarily concerned to re-establish stability in Malawi's external payments. However, one of the main revealed priorities of the Malawi Government was to avoid future domestic food shortages, as had occurred in the south of the country in 1980. For the government, the raising of price incentives for maize producers consequently took precedence over measures to stimulate production of export crops. Maize prices were raised 27 per cent in the $1980-81$ season and a further 68 per cent in the 1981-82 season. As a result, a substantial maize supply response was achieved and a particularly large surplus was generated in 1983-84 (when maize found a ready export market in the region). This, however, became "an uneconomic surplus in 1985 with over 180,000 tons of maize stockpiled, and no profitable outlets for this low value-to-weight crop. This has produced new liquidity problems for the state purchasing and marketing agency, ADMARC. Thus the mix of policies as between support for export crop production and food output has been different from those prescribed by the external donors (and the IMF) and more directly attuned to the government's own political priorities. Nor is this a new phenomenon. Even before Independence, there was a constant tension between the need to maximise foreign exchange earnings and the local administration's food self-sufficiency targets.

This example is not exceptional. The Malawi Government was in conflict with donors at various times in the 1960s and 1970s on spending priorities. When aid was refused for a new rail link through Mozambique, the government secured South African loans instead. Much of the new capital city was constructed with international borrowing, in defiance of donor advice. But unlike Tanzania and Nigeria, Malawi already has a functioning and effective new capital in place. Even the basis of Malawi's agricultural policies was not fully in tune with donor priorities, for the smallholders on whom external aid was focused were the subject of government neglect in favour of estates throughout the 1970s. Furthermore, Malawi's apparent responsiveness to market forces in the productive sectors masks the fact that much of the economy is effectively state-owned through the medium of Press Holdings, and the control exerted by the Malawi Congress Party.

Why has Malawi emerged as a virtuous case among the African 'problem countries' with which donors have to deal? It is less because of genuine absence of state intervention or price distortion, than because Malawi's policy decisions affecting the external sector could be implemented relatively smoothly by an authoritarian government, not beholden to powerful urban interests or organised labour or the military. In the 1970s, the dominant interest group in economic policy was large farmers, the President, Dr. Banda, being the owner of substantial export producing agricultural enterprises.

\section{The Donor Profile}

Within the context of sub-Saharan Africa, Malawi does not appear to be heavily aided given its particular disadvantages - it is classified as 'least-developed' by the UN and is completely landlocked. Over 1979-81, Malawi received an annual average of $\$ 136 \mathrm{mn}$ in aid 
[see Table 1], whereas countries with a similar size of population but higher levels of per capita income received considerably more: for instance Zambia's average ODA receipts over the same period were $\$ 260 \mathrm{mn}$, while Senegal received $\$ 312 \mathrm{mn}$.

From the table it is apparent that Malawi has a relatively narrow range of donor support. The bulk of its concessional external assistance comes from four sources: two major bilateral donors, the UK and West Germany, plus two multilateral agencies. On the multilateral side, the main source of support has been the World Bank's IDA credits. In the 1980s, however, Malawi has been categorised by the World Bank as a 'blend country' eligible for harder IBRD loans (the first Structural Adjustment Loan itself was taken on IBRD terms), so the degree of concessionality in finance from this source may tend to diminish. Since 1975, when the first EDF programme was agreed, aid from the EEC has developed as the second most important source of multilateral assistance, mostly for projects but with a few minor drawings from Stabex to cover certain commodity export earnings losses.

Overall, these four main donors supply over twothirds of Malawi's aid. Although some donors are significant at the intermediate level (Canada has become less important since its railway building programme ended, the USA has a surprisingly small programme, to be increased from 1985 as a result of the new Economic Policy Initiative for Africa, for which Malawi aptly qualifies as a market-oriented economy), what is most striking about Malawi's donor profile is (a) its concentration among a few large donors, (b) the absence of several donors one would expect to see in comparable African count ries - most of the Scandinavian donors and, except for one exceptional item of project financing, OPEC donors and (c) the presence of a group of 'unusual' non-DAC donors; the Republic of South Africa, Taiwan and Israel.

\section{Aid-effectiveness in Malawi}

The sectoral impact of aid is best considered via the project aid interventions which were dominant in the $1970 \mathrm{~s}$, before programme lending for structural adjustment began.

Aid to agriculture has been heavily focused on the peasant sector. The principal vehicle for this aid has been integrated rural development projects (IRDPs), and, at their inception, donors viewed IRDPs as an effective form of poverty-focused aid. The production impact of the IRDPs has been disappointing, mainly because in the 1970s peasant export crop production was implicitly taxed heavily through the government crop marketing board (ADMARC). Other problems
Table I

Total Malawi ODA receipts net, $1979-82$

$(\$ \mathrm{~m})$

\begin{tabular}{lrrrrr}
\hline & 1979 & 1980 & 1981 & 1982 & $\%$ \\
\hline Bilateral & & & & & \\
Germany (FR) & 28.6 & 13.2 & 24.9 & 21.7 & 17.9 \\
UK & 33.2 & 25.4 & 25.0 & 20.4 & 16.8 \\
Canada & 13.3 & 9.0 & 10.0 & 6.6 & 5.4 \\
Japan & 6.9 & 11.6 & 9.9 & 5.7 & 4.7 \\
USA & 3.0 & 3.0 & 4.0 & 4.0 & 3.3 \\
Denmark & 2.2 & 6.0 & 1.6 & 3.3 & 2.7 \\
Total (including & & & & & \\
$\quad$ others) & 92.0 & 75.6 & 82.1 & 65.2 & - \\
Multilateral & & & & & \\
IDA & 13.9 & 14.3 & 19.9 & 26.1 & 21.5 \\
EEC & 12.7 & 20.6 & 14.0 & 10.8 & 8.9 \\
UNDP & 3.6 & 4.9 & 8.1 & 8.0 & 6.6 \\
African DF & 2.0 & 10.9 & 6.3 & 5.9 & 4.9 \\
OPEC & - & 1.3 & 0.5 & - & - \\
Total (including & & & & & \\
$\quad$ others) & 49.7 & 67.7 & 55.6 & 56.2 & - \\
\cline { 2 - 6 } TOTAL & 141.8 & 143.4 & 137.7 & 121.5 & 100 \\
\hline & & & & & \\
\hline
\end{tabular}

Source: OECD Geographical Distribution of Financial Flows, 1983 Report.

' Excluding South Africa, Taiwan and Israel.

were the impact of increasingly severe land pressure in peasant farming areas, an initial under-emphasis on agricultural research on peasant crops except of cotton and tobacco, an over-ambitious and complex management structure (especially in the post-1978 National Rural Development Programme), a weak input distribution system, and the effects of the energy price increases on the viability of the 'technical packages' promoted. IRDPs have already placed a heavy burden on the recurrent budget, leading to considerable difficulties as donor-financed project components. However, most of this potential burden is still to be felt, and is likely to be a critical problem in the mid-1980s, as more projects come to the end of their donor-funded phases.

Future donor support to peasant agriculture should give priority to ensuring a satisfactory macroeconomic climate (a key feature of the second SAL) and to improving the efficiency of the marketing system (which received considerable investment funds in the 
1970s). Beyond this, capital aid should continue to focus on small-farm credit (based on simple, robust administrative models), and on extending whatever capital aid may be required to improve the performance of the marketing system. Malawi's agricultural research system should be expanded at a rate consistent with its continued efficiency, and donors should continue to bear in mind whether, on particular research problems, enhanced support for international crop research organisations might prove a more cost-effective approach to Malawian problems.

Donor interventions in the domestic transport sector were generally very successful. Starting almost from scratch at Independence, Malawi now has a near complete road network, all of it aid-financed. The Ministry of Works has never built a main road with its own budget - local resources have been used only for repairs and maintenance. One road project (in the Shire Valley) was a conspicuous failure in construction terms; in another instance, the government requested roads which duplicated each other, for political reasons; but donors generally fended off such approaches. The initial donor-financed extension to the rail networks, the second route to the coast, was also viable and, subject to a caveat about Malawi's present external transport links through Mozambique, created a new life-line for the export economy. Donorsupplied ships for the Lake service were sometimes mis-specified (by the donor) but were adapted locally. Emergency quick-response aid in this sector also proved effective - a donor quickly supplied a road bridge from Zimbabwe stock when one was washed away, and others responded with alacrity to road construction projects in the north across the Tanzanian border when other export routes became blocked and existing alternatives were imposing undue cost burdens. Regional transport links have, however, been rather slow to develop - as much due to Malawi Government reluctance as to donor procedures - but SADCC initiatives are improving this situation.

Malawi's trade patterns have barely changed as a result of donor involvement. Tobacco has increased its dominance in exports (and hence Malawi's commodity vulnerability) but largely as a result of strong world demand and of directing domestic bank credit to private operators. Sugar expansion has been largely financed by loans and equity investment. European countries still take the bulk of exports (mainly raw commodities), and South Africa remains the leading source of imports. Flagging exports have been a smaller factor in Malawi's balance of payments difficulties than the debt service burden arising from borrowing at commercial rates. But compensatory finance from the IMF has been used twice, successfully, although drawings on Stabex have been small and always less than the claim submitted. Unfortunately, tobacco, the main export, is not covered under this scheme.

Donors have not been heavily involved in 'basic needs', except in the context of 'integrated rural development projects' - health and primary education in particular. Some donors admit to an undue urban bias in their programmes. For the future concerted donor action for the social services is needed, which must involve donors being prepared to fund some recurrent costs as government budgets continue to make inadequate provision for this sector.

Malawi represents only a small market for Western capital goods, but most bilateral donors have responded to the recession by the increasing tradeorientation in their aid programmes. Normally procurement tying to source has not been a major problem - most donors allow derogat ions to procure from low-cost regional sources in exceptional circumstances - but the emergence of mixed credits and some forms of programme aid has shifted donor allocations into non-priority 'sectors such as telecommunications.

In the $1980 \mathrm{~s}$, the leading donor influence on policy has been the World Bank, which initiated a programme of structural adjustment lending in 1981. Previously, World Bank assistance had been almost exclusively project-based, and focused mainly on smallholder agricultural development and on transport and energy infrastructure. Following the 1970 balance-of-payments crisis and the first in a series of the IMF agreements, the government requested a SAL in 1980 , and in June 1981, a loan of $\$ 45 \mathrm{mn}$ at standard IBRD terms was approved for disbursement over two years.

During the first SAL, the government implemented several important 'supply side' reforms. Food prices to producers were greatly improved and the flagging tobacco estate sector was reorganised with beneficial results. These improvements, however, emerged from the domestic policy-making process, and measures to stimulate the peasant export sector and to liberalise wage and price controls, which featured prominantly in the SAL agreement, were underplayed. Despite a 15 per cent devaluation in 1982, and budgetary cutbacks, the debt service burden increased, and there was little progress towards achieving external balance.

The second SAL of $\$ 52 \mathrm{mn}$, on more concessional IDA terms, was approved in November 1983 and brought in much tougher corrective requirements as a condition of the loan agreement. The government agreed to take steps to improve the performance of the productive sectors and, in fact, pre-empted the SAL agreement by raising prices for peasant-produced 
export crops in the range of 29 to 50 per cent in March 1983. It also came under pressure to deregulate retail prices, and in early 1984 a wide range of local products and services (mostly those with high domestic valueadded) were exempted from price control. The requirement to restructure Press Holdings and to rationalise the operations of the parastatals reached deep into the mechanisms of resource control and political patronage in the country, but had to be acceded to. Essentially, Press ceased to be a private concern of Dr. Banda's, and became a parastatal. Similarly, the budget deficit problem was addressed by a series of unpalatable proposals which, on the revenue side, included raising extra resources from cost recovery in the educational and health sectors. The government was, however, also required to reduce public expenditure on non-productive items which had earlier resisted cutbacks, such as the continuing programme for construction of government buildings. The heavy burden of public recurrent spending, partly arising from inherited commitments on donorfinanced projects, has, however, yet to be adequately addressed.

Probably the main impact of the change in World Bank operations from project finance towards 'policy lending' has been to offer a model of productionoriented aid programmes allied to a pre-arranged reform package which can be followed by the other main donors. The hardening conditionality of the first two SALs indicates that, even for a major donor like the World Bank, its intervention into macroeconomic policies proved to be a learning process. ${ }^{1}$ Given Malawi's recent history of success in playing off one donor against another, there is, however, some concern that donors may in future stack up behind the World Bank's guidelines and leave the government with little room for manoeuvre to develop its own viable national policies, and that cross-conditionality between donors and the shorter-term IMF adjustment packages could also limit the scope of Malawi's traditional dialogue with individual donors. On balance, however, if reform proposals are adequately coordinated, not merely between donors, but in full consultation with the government, aid-effectiveness can be further enhanced. We therefore need to investigate the extent of donor proliferation and the reality of aid coordination at national level.

\section{Donor Proliferation and Institutional Destruction: Questioning the Evidence}

A recent analysis [Morss 1984] claims institutional destruction' by donor activity in SSA (at least during

\footnotetext{
' Structural adjustment loans are not analysed in detail in this article. Readers interested in this aspect of aid-effectiveness in Malawi should see the paper by Hewitt and Kydd. 'The effectiveness of structural adjustment lending: initial evidence from Malawi' in World Development, Vol 14, No 3, 1986.
}

the 1970s). It is alleged that donor agency proliferation leads governments to waste time and scarce skilled manpower (in pandering to donor whims, applying individual agency headquarters procedures and requirements, and adjusting national development policy to prevailing donor fashions), and to alter their carefully-established spending priorities and economic planning to suit individual donors. For Malawi, Morss claims three main forms of this 'institutional destruction':

(a) Too many donors -50 , according to UNDP;

(b) Nefarious effects from the 800 person-years of expatriate technical assistance, many in line posts, and deemed to hinder (or definitively stunt) national decision-making and managerial capacity;

(c) A donor 'onslaught' of proliferating, uncoordinated projects in response to sectoral ministries' requests.

Morss's evidence seems to be the current conventional wisdom [World Bank 1985]. Citing the evidence from several small and medium-sized countries in Africa, (Kenya, Lesotho, Zambia) and also Malawi where the UNDP has estimated that there were 188 projects from 50 donors' the 1985 World Development Report alleges that 'in such numbers, the effectiveness of aid can be severely reduced; . . . the proliferation of projects may actually have undermined the development effort of individual countries'.

We dispute these analyses. As shown below, Malawi deals effectively with a relatively narrow range of main donors; coordination behind a main donor 'core' is increasing; and the interventions of peripheral donors have been rarely obtrusive or obstructive, and sometimes rather helpful (see (a) below). Also, particular programmes of technical assistance have very successfully strengthened the institutional capacity of the public (and perhaps recently the parastatal) sector; have embodied a useful training function; and have gradually evolved into active programmes of institutional support rather than mere post-colonial 'gap-filling' (sub-section (b)). Finally, project proliferation is simply not the aid reality of today, though it did have deleterious effects in certain sectors in the 1970 s, particularly where donors designed projects at home without due reference to Malawi's needs and conditions.

\section{(a) Agency Proliferation}

Only eight donors give more than about $\$ 5 \mathrm{mn}$ in aid annually to Malawi. Within this group, there is a core of four main donors - the UK, West Germany, the World Bank and the EEC - which maintain substantial programmes (ie each worth about $\$ 20 \mathrm{mn}$ 
per annum). Though not conventionally a concessional source, the IMF should be added to this core, making five powerful external donor influences. Even within the narrow range of main donors, there is an emerging tendency of concentration, certainly on the part of the two big bilateral donors, the UK and Germany, behind the strategies of the World Bank and the IMF (though, like the government, we are aware of strains between and differing objectives within these two multilaterial institutions).

Nor have the activities of peripheral donors been disruptive or conflict-inducing. At the intermediate level, the African Development Bank has proved an effective and liberal interlocutor for Malawi's infrastructured investment programme; the Canadians have successfully concentrated on railway-building; the Danes, on small health projects. Even some of the smaller donors such as South Africa, though poorly integrated into any multi-donor dialogue, have been adept at picking up particular projects which had high political priority for the government and subsequently proved to be economically justifiable though not supported by the main donors. Moreover, some progress has been made on important development issues such as population policy - in the form of 'birth spacing' proposals - thanks largely to the more peripheral donors who have relatively few interests at stake. Nor is Malawi afflicted by a proliferation of small non-governmental agencies: the evidence is rather to the contrary, since many of the more socially conscious development and relief agencies have either not been attracted to Malawi or have run down their programmes there.

A more pertinent question than 'are there too many donors?' is the extent to which both the bilateral donors and the Malawi government can be consulted early in the formulation of macroeconomic adjustment programmes, which loom large in multilateral aid in the 1980s. The evidence here has not always been reassuring. Of the main donor agencies, only the UK and the EEC have a local representation in the form of an office including economic and technical specialists dealing specifically with development assistance. The others operate through embassies (often merely through a locally-based commercial attache). The World Bank, until 1985, had no local office, and operated through visits.

\section{(b) Technical Assistance}

Of the UK aid programme (which for historical reasons has always been the largest in Malawi) some 55 per cent - ie about $£ 13$ mn out of $£ 25$ mn annually - now comprises manpower support. This has been broadly the case ever since Independence. The second largest TA programme is UNDP (about $\$ 8 \mathrm{mn}$ per year). In 1983, of 600 expatriates in middle and senior positions, half were British-supplemented. British TA is unusual in its longstanding emphasis on salary supplementation of expatriates in post, rather than (as in the case of UNDP and others) short-term contracts to supply experts or project-linked TA. Where the Malawi authorities have wanted to localise key civil service posts, there has been little or no evidence of donor opposition or obstruction (indeed, localisation may recently have proceeded too fast as a result of UK policy shifts from supplementation towards fewer, but fully-funded, TA posts), nor of donor intervention in the national decision-making process through the TA supplementation programme. This succeeded in keeping a competent body of experienced people in post in the national administration. This continuity in experience enhanced institutional competence through their training function. It assisted, in particular, the administration's capacity for project preparation and implementation, especially when dealing with donor agencies.

Two-thirds of Malawi's overseas training is now financed by bilateral aid, compared with one-third three years ago. Donors are now more alert to integrating TA support into sectoral programmes. In the case of the UK, supplemented personnel are now more concentrated in Education (which itself absorbs about 50 per cent of the UK supplemented staff in post), Works and Natural Resources. An even more valuable training and policy review function could be provided if donor TA representatives systematically conducted aid evaluations with Malawians, and reported to an impartial body removed from the aid planning and implementation process.

\section{(c) Project Proliferation}

At any time in recent years, the Malawi Government has been implementing 80 to 100 donor-financed projects, plus 20-25 with 'own resources'. (By subdividing projects in component parts, one could arguably reach 188 [see World Bank 1985].) But the government's development policy document presented to the 1984 International Conference on Partners in Development lists approximately 200 discrete development projects (36 in agriculture alone) for funding over the three-year period 1983/86. The second volume covering the five-year period 1984/85 to $1988 / 9$ lists 167 projects. Large though these figures may be, they appear commensurate with the needs and implemention capacity of Malawi's varied economy and diversified public service.

Moreover, project numbers have shrunk in recent years. Key donors and lenders such as the World Bank and IMF have stepped up the share and volume of programme lending. Other agencies, notably the UK's 
ODA, have been at pains to narrow down the range of small project interventions and to initiate programmes of sectoral support (integrating TA, capital aid and import support for key development sectors). Also, such donors have made aid conditional upon the pursuit of internationally agreed sectoral targets and policies under the aegis of World Bank Structural Adjustment programmes. Finally, some 'project consolidation' (particularly in the agricultural sector under the National Rural Development Programme) is occurring. Project proliferation is simply not the aid reality of today.

This is not to claim that project proliferation in the 1970 s can be completely dismissed as a barrier to aid-effectiveness. Donor-designed agricultural projects have built up unwarranted recurrent costs for the local administration to inherit. Another problem induced by a decade of multi-donor operations has been the institutional response within the government, and specifically within the Office of the President and Cabinet. A separate division, the Development Division has been set up therein, parallel to the Economic Planning Division and separate from the Treasury (which ultimately coordinates aid offers and departmental spending priorities). The raison d'etre of the Development Division has become, perhaps naturally but nevertheless unproductively, to administer development initiatives in the form of projects. Thus, even in the more straitened circumstances of the $1980 \mathrm{~s}$, the Division was until very recently encouraging new project submissions rather than coordinating programme aid requirements and consolidating the project initiatives sponsored by the range of donors already present in Malawi. Reforms were introduced in 1984-85. Nor have bilateral donors been averse to 'projectising' initiatives which might more suitably be supplied in other forms: we cited the example earlier of export-oriented donor trade strategies influencing the provision of specific capital goods in mixed credit projects.

Lastly, we can illustrate some of the pitfalls on the donor side when devising project interventions. Without a strong local bureaucracy, it is possible for donors to arrive equipped with outside models for projects devised either to meet requirements in an alien environment or simply to suit the sort of mix of goods and services which donors wish to unload. With due deference to individual donors, it is probably worth citing two instances of inappropriate project design. The German model of 'rural growth centres' was in fact a model of growth poles devised in Berlin for use in small border communities in West Germany which had become spatially marginalised with the division of Germany and the erection of the Iron Curtain. Such models have of course some scope for adaptation, but it is clear that this was not the most fruitful starting point for enlivening rural communities in Malawi. Nor could the adapted model, with its heavy emphasis on costly municipal infrastructure which local district councils could not possibly support even on a minimal cost recovery basis (given the very low incomes of rural Malawians) have been worthwhile. Though the Ministry of Agriculture resisted the project proposal, it was nevertheless proceeded with, and absorbed both local and donor funding by being placed with a special unit within the Office of the President and Cabinet.

Another foreign project design had a different genesis. The UNDP-sponsored programme of low-cost rural housing schemes evolved from an international conference on low-cost housing methods. Such conferences tend inevitably to propose general solutions to general problems and the result was less than adequately Malawi-specific. Although designed to provide low-cost rural housing, the project as implemented so far has been neither low-cost (in relation to normal rural housing built without donor assistance) nor rural - the main project has been executed in Zomba, formerly the national capital.

These examples do not however undermine the general finding that donor support has been generally well-coordinated, focused on the leading agricultural production sector and on the country's infrastructure base (with perhaps inadequate attention to the primary education and health sectors) and that far from proliferating, aid interventions are becoming increasingly directed behind the major adjustment strategies in the 1980s. A major government ambition behind the organisation of the UN-sponsored Donors' Round Table in 1984 was in fact to extend Malawi's network of donors into unfamiliar territory (OPEC multilaterals, Arab national agencies, Scandinavian donors) and thus to extend the project mix on offer to Malawi.

\section{Key Factors from Malawi's Aid Experience}

Malawi is seen as a relatively successful case among the aid-assisted economies of Africa because its economy managed to grow fast from a relatively low base, securing high aggregate returns on investments, especially in the 1970s, and because the policies adopted domestically never flinched from a singleminded concent ration on the agricultural sector. Even when, in the $1980 \mathrm{~s}$, donors began to adopt a new role of administering corrective medicine to an ailing economy, Malawi's performance in recovery has been impressive. On crucial issues of national interest, the government was careful to undertake certain key policy reforms before they became a source of dispute with the donors. For instance, the inefficiencies of the large farm sector were addressed by direct action 
through the commercial banks, and producer prices for maize raised by government action long before the issue of relative pricing policy between food and export crops could harden into a dispute with the World Bank. Wherever possible, Malawi seems to have taken pre-emptive action rather than let issues slide into confrontation with the donors. Implementing unpalatable policy reforms is never easy; for that reason some governments may prefer to use an external agent as scapegoat for its austerity programme. Malawi has adopted a different stance. Since the government had never been forced to depend on powerful non-agrarian interests, in the public sector and among the military, it was able to secure the backing of agricultural interests which were not averse to devaluation, public spending cuts and wage restraint, when pressures for external stabilisation required such measures.

The policy environment in which donors operate has also been assisted by the relatively narrow range of donors operating in Malawi. The tendency towards concentration has increased in recent years as bilateral donors began to link their aid projects to the structural reforms agreed with the multilateral bodies. The converse of this situation is that Malawi remains a relatively under-aided country, there being very few 'footloose' donors present who are prepared to pick up marginal projects. But because there is still competition among donors to secure the best projects, in general there have been fewer 'white elephants' than could be observed in several neighbouring countries. Malawi's strategy for dealing with donors contributing to nation-wide sectoral programmes has also been effective. For instance, under the current national rural development programme, the government endeavours to associate an individual donor with a single agricultural development division and so concentrate its resources in a given area.

Because Malawi was so bereft of a basic transport network at Independence, and because its international links have needed to be progressively reoriented towards the eastern ports and the northern access route, nearly all the aid for major infrastructure projects in the transport sector has proved its worth. Such projects gave an indirect boost to agricultural marketing and exports, and have been much more easy to manage and implement than projects aimed at directly stimulating peasant production. They also appeal more to bilateral donors since they embody more capital equipment which can be supplied under tied aid. This argument can however be taken to extremes, and donor competition for supply contracts in the telecommunications sector, for example, tends to distort the country's investment priorities.

Malawi's policies on localisation, whether in govern- ment or in the private sect or have been very restrained, at least as regards fairly senior posts. As a result, Malawi has been able to obtain the benefits of longterm technical assistance which proved an important vehicle for institution building, while other governments curtailed this crucial manpower input for narrow nationalistic reasons but were later obliged to reverse their policies under donor pressure.

Lastly, Malawi's effective use of resources, whether external aid or domestic, was helped by its general policy of conservatism. This meant that the Malawi Treasury was never totally in awe of aid donors bearing gifts, but consistently kept the issues of recurrent costs arising from donor intervention in its agenda for discussions with the donors. The Treasury's strong control over the sectoral ministries also meant that project proposals had to be carefully ranked in order of priority. Although a few striking examples of public expenditure projects of low merit slipped through the net - it would be dishonest to conclude this article without a mention of some extravagances on presidential palaces - in general, donors were assured by the strength of the centralised and autocratic administrative machinery that their projects were of genuine high developmental priority, and that there was little shunting of donor resources to fund consumption expenditures.

\section{References}

Hewitt. A. and J. Kydd. 1984, Aid Effectiveness in Malawi. Report to the Task Force on Concessional Flows

Morss. E. R., 1984. 'Institutional destruction resulting from donor and project proliferation in sub-Saharan African countries. World Development. vol 12. no 4

Ramgopal. A., 1983. Price Distributions and Grou'th in Developing Countries, World Bank Staff Working Paper No. 575. Washington DC

World Bank. 1983. World Development Report. Washington DC

World Bank, 1985, World Development Report. Washington DC 


\section{Books Received}

S. D. Joseph, Y. M. Shanahan and W. Stewart, The Stove Project Manual: Planning and Implementation, Intermediate Technology Publications, London, 1985

Peter Ward, Welfare Politics in Mexico: Papering over the Cracks, Allen \& Unwin, London, 1986

Andrei Rogers and Frans J. Willekens (eds.), Migration and Settlement: A Multiregional Comparative Study, D. Reidel, Dordrecht (Netherlands), 1986

Dennis John Gayle, The Small Developing State, Gower, Aldershot, 1986

M. Anandakrishnan (ed.), Planning and Popularising Science and Technology in Developing Countries, Tycooly for the UN, Oxford, 1985

Warren C. Baum and Stokes $\mathrm{M}$. Tolbert, Investing in Development: Lessons of World Bank Experience, Oxford University Press (USA), 1986
Stephany Griffith-Jones and Charles Harvey (eds.), World Prices and Development, Gower, Aldershot, 1985

Altaf Gauhar, Shared Horizons: Interviews with Leaders of Thought, Third World Foundation, London, 1985

Edna S. Angeles, Public Policy and the Philippine Housing Market, Philippine Institute for Development Studies, 1985

Institute for Policy Studies, From Debt to Development: Alternatives to the International Debt Crisis, Washington DC/Amsterdam, 1985

Rod Hitchings, How to Make a Folding Machine for Sheet Metal Work, Intermediate Technology Publications, London, 1985

- How to Make Cutting-Shears for Sheet Metal, Intermediate Technology Publications, London, 1985

- How' to Make a Rolling Machine for Sheet Metal Work, Intermediate Technology Publications, London, 1985

Robert Repetto, Paying the Price: Pesticide Subsidies in Developing Countries, World Resources Institute, Washington DC, 1985 